\title{
THE TOURISM-LED GROWTH HYPOTHESIS IN TRANSITION ECONOMIES? EMPIRICAL EVIDENCE FROM A PANEL DATA ANALYSIS
}

\author{
Le Thanh TUNG* \\ Ho Chi Minh City Open University, Faculty of Economics and Public Management, \\ Policy and Applied Economics Research Group, Ho Chi Minh City, Vietnam, e-mail: tung.lt@ ou.edu.vn
}

\begin{abstract}
Citation: Tung, L.T. (2021). THE TOURISM-LED GROWTH HYPOTHESIS IN TRANSITION ECONOMIES? EMPIRICAL EVIDENCE FROM A PANEL DATA ANALYSIS. GeoJournal of Tourism and Geosites, 38(4), $1076-1082$. https://doi.org/10.30892/gtg.38412-746
\end{abstract}

\begin{abstract}
Tourism has been considered as a potential factor in development strategy in many developed and developing countries worldwide. Besides, tourism is really a key economic sector in some countries. This study aims to examine the tourism-led growth hypothesis for some transition countries, which includes seven high growth economies Bulgaria, Hungary, Poland, Romania, Russia, Ukraine and Vietnam. The research database is collected by an annual form in the period of 19952019. These economies are considered successful transitional cases in the global economy, however, the tourism-led growth hypothesis in these countries has been received only a little evidence from academics in recent years. The Johansen-Fisher test and the OLS estimation are applied in the quantitative process. There are some new findings from the empirical results. First, the Johansen-Fisher test confirms the existence of long-run cointegration relationships between tourism (denoted by the tourism revenue and the tourism arrivals) and economic growth in the panel data sample of countries. Second, the long-run coefficients of the tourism variables are positive and significant that concludes the tourism-led growth hypothesis in these transition countries. The contribution of the study is not only to fill the empirical research gap by the estimated results from a group of transition economies but also to confirms the tourism-led growth platform as an efficient development strategy for other developing countries. Furthermore, our study suggests some policy implications for policymakers to use tourism as a key development sector in these countries in the future.
\end{abstract}

Key words: Tourism-led growth, Economic development, Economic policy, Cointegration test, Transition countries

$* * * * * *$

\section{INTRODUCTION}

Tourism is now popularly recognized as one of the largest service industries in the world and one of the most significant sources of national output and economic growth rates in many countries (Balaguer and Cantavell-Jorda 2002; Lew, 2011; Pablo-Romero and Molina, 2013). On the other hand, tourism particularly benefits the people in developing countries, where need new jobs and business opportunities (Brida and Risso, 2010). Besides, tourism development creates a positive effect on the income of local people as well as brings new demands for local businesses (Balaguer and Cantavell-Jordá, 2002; Lim and Zhu, 2017). Furthermore, tourism development makes a critical spillovers effect on the local economy and leads to the growth of other major industries (World Economic Forum, 2019), for example, manufacturing sectors, financial services and retail systems (Chen, 2007; Cárdenas-García and Sánchez-Rivero, 2015; Aratuo and Etienne, 2019). Considered as financial flows of foreign currencies, from the social perspective, tourism is understood as a "smokeless industry" that has helped millions of people in many regions out of poverty (Saayman et al., 2012; Njoya and Seetaram, 2017; Garza-Rodriguez, 2019; Tung, 2020).

Besides some positive aspects, there are some concerns related to the high growth of tourism, for example, the destruction of the natural environment (eg., Strydom et al., 2019; Firdaus et al., 2019) or rapid urbanization of tourism cities, deforest and destroy the natural landscapes (Scott et al., 2016). Although, tourism is one of the fastest-growing service industries of the world economy, there are debates about the real relationship between tourism and economic growth. Many empirical studies confirm the tourism-led growth hypothesis (eg., Nowak et al., 2007), on the other hand, some empirical results do not find evidence in supporting this hypothesis (eg., Kyophilavong et al., 2018). Hence, there are demands of investigating the real relationship between tourism development and economic growth in a specific country or specific group of countries. However, tourism has been found to have an important role in economic development in many countries worldwide (Balaguer and Cantavell-Jorda, 2002; Brida and Risso, 2010).

On the other hand, economic growth and the sources of growth in countries are always considered as the spotlight topic in the economic theories (eg., Grossman and Helpman, 1990; Barro, 1991). In the context of globalization is increasing, obviously, tourism is more closely connecting countries worldwide year by year (Ivanov and Webster, 2013). Based on the previous arguments, the tourism sector and tourism activities have been significantly supported economic growth in many countries (Pablo-Romero and Molina, 2013; Tugcu, 2014). The empirical results are quite diverse in both theoretical and empirical research (Brida and Risso, 2010; Tugcu, 2014; Brida et al., 2016). There are some studies

\footnotetext{
* Corresponding author
} 
that show a positive impact of tourism on economic growth and confirm the tourism-led growth hypothesis in the countries (Tugcu, 2014). However, tourism-led growth has been not found in some empirical studies, such as Kyophilavong et al. (2018) in Laos or Gričar et al. (2021) in Slovenia. Besides, global economic-financial crises or global pandemics have highlighted the potential risks of the tourism-led growth model for the applied countries when their economies close link with international value chains of the global tourism industry (Weidenfeld, 2013; Aratuo and Etienne, 2019). In recent years, there have had many previous studies in developed countries (Balaguer and CantavellJorda, 2002; Nowak et al., 2007; Katircioğlu, 2010; Aratuo and Etienne, 2019) some previous results from developing countries (Trang et al., 2014; Tugcu, 2014) or island countries (Katircioglu, 2009).

However, there are a few empirical studies in transition countries, which have robust growth rates in tourism sectors. Transition countries are popularly understood as the economies that have been changing from a centrally planned model to a market economy. The transition countries need to undergo economic structural transformations to help develop market-based institutions. The solutions are economic liberalization and remove international trade barriers. Tourism has many opportunities to develop in the group of transition countries. Because of high economic growth rates, some transition countries have been listed in the group of emerging economies (which is expected as a new engine of the world economy in the next decades), therefore, the role of tourism in improving economic growth is an interesting research topic. However, there are no previous results that focus on the impact of tourism on growth with a panel data sample of the transition economies, hence, this study aims to fill this empirical research gap in the current literature.

In order to fill the empirical research gap of the impact of tourism on economic growth in transition countries, in this study, the tourism-led growth hypothesis will be examined with a panel database collected from selected countries including Bulgaria, Hungary, Poland, Romania, Russia, Ukraine and Vietnam. In recent decades, the transition economies have robustly opened their domestic markets to join the global trade and international value chains. These countries are chosen following the available in the database as well as robust development in their tourism sectors. In detail, the statistics from the World Development Indicators (World Bank, 2021a) show that the GDP per capita of the transition countries has been increased significantly in recent decades (Figure 1).

For the period 2005-2019, in the European region, Romania has achieved the highest growth at 3.3 times in the GDP per capita (from nearly 9.6 thousand\$ to 32.3 thousand\$), besides, Poland, Russia, and Bulgaria have increased around 2.4 times. In 2019, Hungary and Ukraine have had the lowest growth level at 1.9 times compared to 2005 . In the Asian region, Vietnam is a transition country that always ranked in the group having the highest growth rate. This country has raised its GDP per capita from nearly 2.9 thousand\$ to 8.4 thousand\$ for this period (as 2.8 times). Although Vietnam has the lowest GDP per capita in 7 transition countries, this economy is expected to successfully join the high-income group in the next years. The interesting question is why some transition countries grow so fast? Compare to the other countries, obviously, these transition economies have reached significant growth in recent decades.

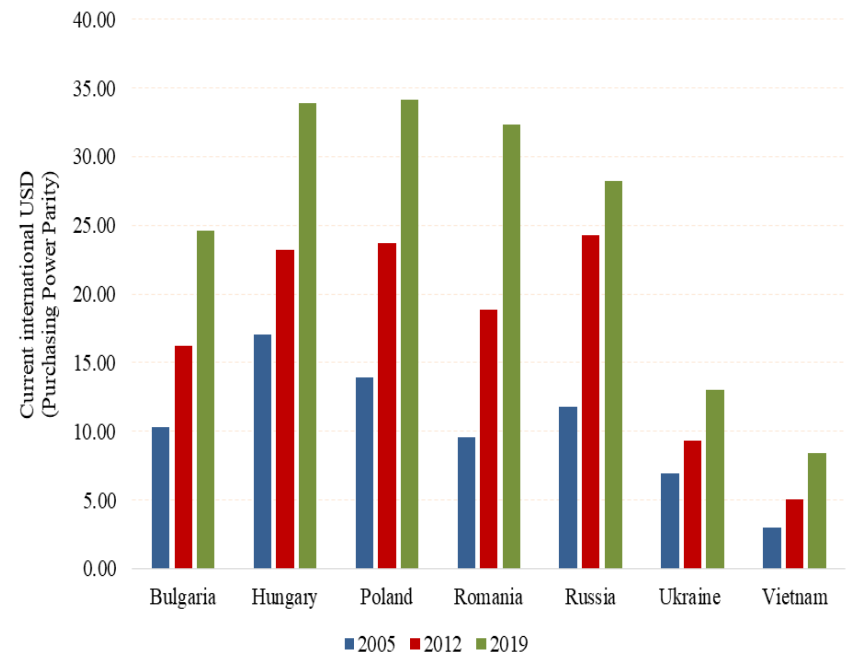

Figure 1. The GDP per capita in some transition countries (Source: World Development Indicators - World Bank, 2021a)

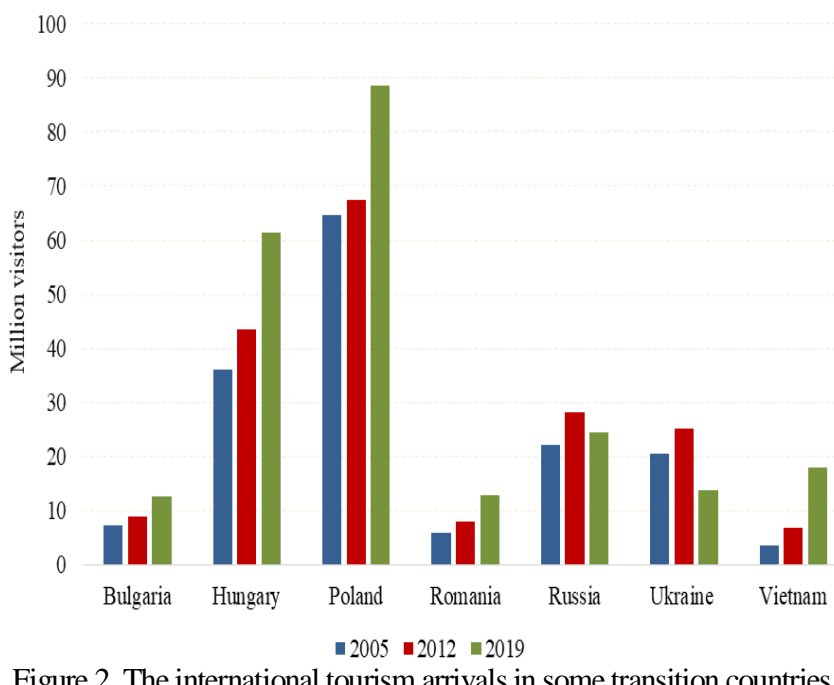

Figure 2. The international tourism arrivals in some transition countries
(Source: World Development Indicators - World Bank, 2021b)

Over the same period, 2005-2019, besides the fast growth of the economies, the statistics from the World Development Indicators (World Bank, 2021b) also indicate that the international tourism arrivals of these transition countries have also increased at high levels. In particular, the total number of international tourism arrivals into this group was 160 million visitors in 2005, reached 160 million visitors in 2012, and had 231 million visitors in 2019 (raised 1.5 times for the period). The statistics show Poland is the largest tourism market amongst seven transition countries (at 88.5 million international visitors). Hungary is the second one with a number of international visitors is 61.4 million people (World Bank, 2021b). The figure of the number of international tourism arrivals also confirms that tourism might have a significant role in supporting economic growth in these countries (Figure 2).

The transition economic process requires adjusting institutional economic systems, particularly in supporting the development of private companies. Therefore, tourism is helpful when it creates many opportunities for small and 
medium enterprises as well as enhances the start-up activities from the private sector. Besides, based on the tourism development, the domestic markets are received new demands of products and services and help to close the link between domestic markets and the global market. The transition model appears in different ways where domestic enterprises increase their profits and practical business modes in the markets. In essence, tourism is good for the functional restructuring of public business institutions from being a provider of growth to an enabler, on the other hand, the main engines of economic growth are the private sectors, for example, private companies in the tourism sector. However, there are not any empirical studies related to the examination of the tourism-led growth hypothesis, using panel data, for this group of transition economies. On the other hand, some related studies were being done with old databases, therefore, the values for the policymaking process are quite limited.

Totally, by examining the tourism-led growth hypothesis in this group of transition economies, this study has some contributions. First, this study focuses on the topic of tourism- economic growth nexus in seven transition countries. The empirical evidence helps to fill the current research gap in the development literature. Second, based on the estimated finding, the empirical result suggests for the policymakers to increase the efficiency of the policymaking process. Third, the investigated evidence is a good reference for other developing countries to well employ the tourism-led growth strategy in their development economic plans. Besides, the database of this study is the newest one which was directly collected from the World Development Indicators (World Bank, 2021a, 2021b, 2021c) in the period of 1995-2019. Therefore, the empirical evidence of this study can help as much as possible for the policymaker in the countries. The paper includes 5 sections. Section 2 is the literature review. Section 3 presents the econometric model, methodology and data source. The estimated results and discussions are shown in section 4. Finally, conclusions and suggestions are covered in Section 5.

\section{LITERATURE REVIEW}

Economic growth is the central topic in development theories worldwide (eg., Grossman and Helpman, 1990; Barro, 1991). Basically, the tourism-led growth hypothesis is a theory that tries to identify another source to support economic growth (Balaguer and Cantavell-Jorda, 2002), besides the traditional sources such as increasing the amount of labour and capital within an economy. Since the beginning of the 2000 s, the tourism-led growth theory has appeared as one of the most popular topics in the tourism literature with a number of empirical studies investigating the potential impacts of tourism on economic development over the world (Ivanov and Webster, 2013). Therefore, the examination of the tourism-led growth hypothesis is considered as the main study line in the tourism economic literature. Based on some investigated results, the tourism sector and tourism activities are noted as a robust motivation in enhancing the economic development in many countries. For two near decades, there have been some researchers studied the tourism-led growth in developed countries (eg., Nowak et al., 2007) or developing countries (eg., Chen, 2007) or island economies (eg., Katircioglu, 2009; Seetanah, 2011). However, there are a few previous results related to the case of transition economies, besides, the database is employed may be quite old. Hence, in this literature review, our study is only discussing some recent empirical evidence which much relates to the transition economies. In the European region, Payne and Mervar (2010) analysis the tourism-growth nexus in Croatia by quarterly data was collected from 2000-2008. The empirical study confirms the tourism-led growth hypothesis for the Croatian economy.

Besides, Surugiu and Surugiu (2013) analysis the long-run relationships between tourism expansion and economic growth in Romania during the period 1988-2009. The empirical evidence suggests the tourism-led growth hypothesis in this country. Besides, the quantitative results emphasize the important role of national tourism development strategies for supporting the tourism sector. On the other hand, Shahzad et al. (2017) test the tourism-led growth hypothesis in the top ten tourist destinations worldwide (includes Russia). The estimated results primarily show positive relationships between tourism and economic growth for these countries. Gričar et al. (2021) investigate the tourism-led economic growth in Montenegro and Slovenia, which are considered like newcomers on the international tourist destinations map. The empirical database is a monthly form in the period of 2010-2019. as an endogenous variable. There is a long-run cointegration relationship between tourism and economic growth in Montenegro and one cointegrated vector. However, the result confirms no cointegration vector for Slovenia.

Furthermore, Trang et al. (2014) analysis the impact of tourism on growth in Vietnam during the period of 1992 2011. The results indicate the high efficiency of the solutions of the government to enhance economic growth through the tourism sector in Vietnam. However, the contribution of the hotel and restaurant sector is found having relatively low compared to the potential. Kyophilavong et al. (2018) examine the tourism-led growth hypothesis in Laos in 19922014. The empirical evidence confirms that the tourism-led growth hypothesis is rejected in the case of Laos. The main reasons are the weak link between the tourism sector and the rest of the economy, besides, this country has poor infrastructure and a shortage of skilled labour in tourism sectors. Tung and Cuong (2020) examine the impact of tourism on poverty in Vietnam by a panel database collected from 61 provinces in 2010-2018.

The empirical results confirm that tourism has a negative and significant impact on poverty in the study period. In detail, a higher tourism revenue leads to a lower poverty rate in the provinces. The study results suggest policymakers should use tourism as a key factor to sustainably reduce the poverty rate of households in the future. In overview, follow the review of previous results in the group of transition countries, the effect of tourism on economic growth is quite different and depends on the social-economic characteristics of each country. There are a few studies that focus on transition countries, besides, most of the empirical studies employ the old databases which can lead to much bias in the policy-making process in the current context. Furthermore, to the best of our knowledge, there is no evidence using a 
panel database focused only on the tourism-led growth hypothesis of the transition economies. Hence, this study will contribute to filling this empirical research gap in the current literature of the tourism-growth nexus.

\section{RESEARCH MODEL AND DATA SOURCE}

The estimated strategy has three steps. First, the panel unit root test is employed to check the stationary phenomenon of the variables. Three panel testing methods for the unit root are used including the Levin-Lin-Chu (LLC) (see Levin et al., 2002), the Breitung (see Breitung, 2000) and the Im-Pesaran-Shin (IPS) (see Im et al., 2003). Second, the Johansen-Fisher test (see Maddala and $\mathrm{Wu}, 1999$ ) helps to identify the cointegration relationship between variables. Third, the long-run estimated results are done by three panel regressive methods (the pooled-OLS, fixed effects and random effects). By comparison with the estimated results, the tourism-led-growth hypothesis will be concluded in the case of some transition countries in the research sample. In order to test this hypothesis, the impact of tourism on economic growth is presented by the following equations (Balaguer and Cantavell-Jorda, 2002; Seetanah, 2011; Kyophilavong et al., 2018).

$$
\begin{aligned}
& \log Y_{i, t}=\lambda_{0}+\lambda_{1} \log T o u r i s m \_r e v e n u e_{i, t}+u_{i, t} \\
& \log Y_{i, t}=\varphi_{0}+\varphi_{1} \text { LogTourism_arrival }_{i, t}+v_{i, t}
\end{aligned}
$$

Where the $\operatorname{LogY}$ is the natural logarithm of the real GDP, LogTourism-revenue is the natural logarithm of the real expenditure of international tourists, and LogTourism-arrival is the natural logarithm of the number of international tourists, $\mathrm{u}_{\mathrm{i}, \mathrm{t}}$ and $\mathrm{v}_{\mathrm{i}, \mathrm{t}}$ are the error terms. Besides, $\mathrm{t}$ denotes time periods, and $\mathrm{i}$ is the cross-sectional unit with $\mathrm{i} \epsilon[1, \mathrm{n}]$.

The study uses an annual database having seven transition countries (Bulgaria, Hungary, Poland, Romania, Russia, Ukraine and Vietnam) in the period of 1995-2019. Besides the availability of the database, these transition countries are selected because they are recently included in the group of emerging economies, which have robust growth rates. This database (Table 1) is directly downloaded and calculated from the data bank of the World Development Indicators (World Bank, 2021a, 2021b, 2021c). In order to test the tourism-led growth hypothesis, the dependent variable is economic growth, which is measured by the natural logarithm of the real gross domestic product (real GDP). The independent variable is the tourism variable, which is denoted by two kinds of indicators, the first is the natural logarithm of the real tourism revenue (measured by the international tourism expenditure indicator), and the second is the natural logarithm of the number of international tourism arrivals. The real values are adjusted by the GDP deflator indicator. To the best of our knowledge, this database maybe is the best one by its high quality and the international comparable statistic available. The descriptive statistics of the database are presented in the following table. Combined with the descriptive statistical analysis, the graphing techniques are employed to represent the potential impacts of tourism on economic growth in the countries in the study sample. To further illustrate the quantitative results in the next section, two scatter plots are drawn based on the study

Table 1. The statistical summary of the variables (Source: Calculated from the research data)

\begin{tabular}{|l|c|c|c|}
\hline \multicolumn{1}{|c|}{ Statistic } & LogY & LogTourism-revenue & LogTourism-arrival \\
\hline Mean & 28.08290 & 16.56385 & 24.43106 \\
\hline Median & 28.01100 & 16.50628 & 24.72100 \\
\hline Maximum & 32.77800 & 18.30547 & 28.70400 \\
\hline Minimum & 20.92600 & 14.11636 & 17.47500 \\
\hline Std. Dev. & 1.948059 & 1.015773 & 1.940827 \\
\hline Skewness & -0.257640 & -0.128062 & -0.527207 \\
\hline Kurtosis & 3.539991 & 2.284069 & 3.605169 \\
\hline Jarque-Bera & 4.062215 & 4.215728 & 9.730281 \\
\hline Probability & 0.131190 & 0.121497 & 0.007711 \\
\hline Observations & 175 & 175 & 158 \\
\hline
\end{tabular}

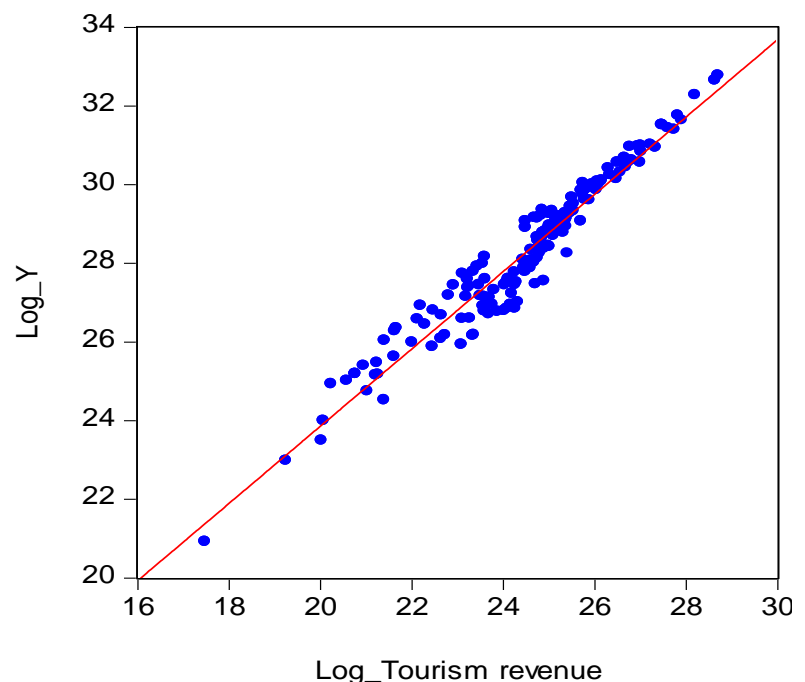
data (Figure 3). The vertical axis shows the natural logarithm value of the real GDP $(\log Y)$ and the horizontal axis presents the natural logarithm value of the real tourism revenue (LogTourism_revenue), the natural logarithm value of the real tourism arrival (LogTourism_arrival) in the same period, respectively. Furthermore, two linear regression lines are drawn to illustrate the expected relationship between these variables. Besides, the scatter plots imply positive relationships between the Log Y and LogTourism_ revenue as well as the $\log \mathrm{Y}$ and the LogTourism_ arrival. Therefore, the tourism-led growth hypothesis can be expected to confirm the case of these transition countries for the study period.

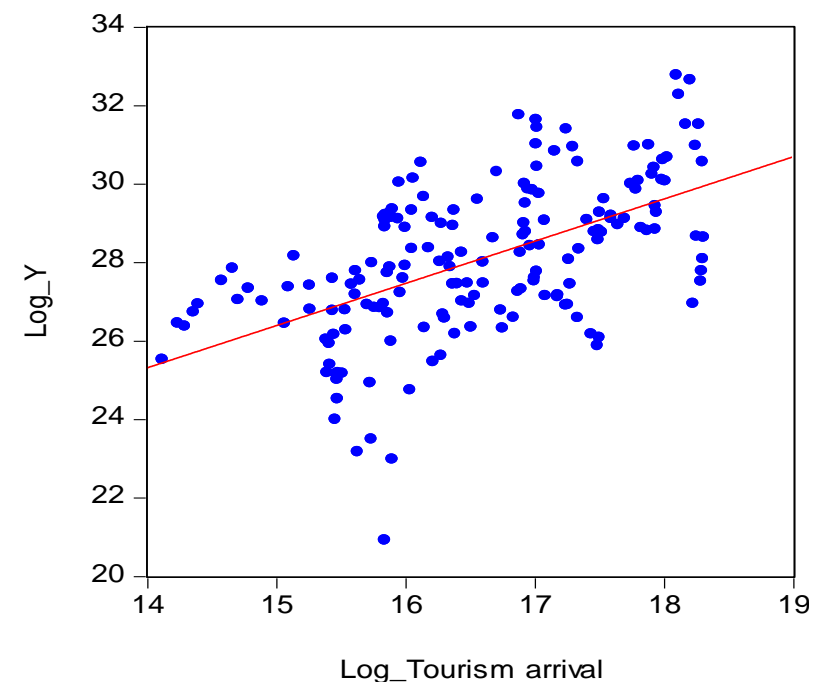

Figure 3. The graphs of the relationships LogY-LogTourism_revenue and LogY-LogTourist_arrival (Source: Calculated from the research data) 


\section{RESULT AND DISCUSSION}

As mentioned in the estimated strategy, first, the variables are tested for unit roots and for cointegration between tourism and economic growth. Based on the testing results, all the tests including LLC (Levin-Lin-Chu), Breitung and IPS (Im-Pesaran-Shin) indicate that the $\log Y$ and $\log$ Tourism_revenue variables are stationary, both level data and first difference data, at the significance of $1 \%$. The LogTourism_arrival is non-stationary at level, however, the application of the first difference values confirms this variable is stationary at the significance of $1 \%$. Hence, the tests imply that the variables are integrated of order one I (1). The optimal lag is chosen by the reference from the Akaike Information Criterion (AIC). The results of the unit root tests are shown in the below table (Table 2 and Table 3 ).

Table 2. Result of the panel unit root test

(Source: Calculated from the research data)

\begin{tabular}{|c|c|c|c|}
\hline \multicolumn{4}{|c|}{ In the level } \\
\hline Method & $\operatorname{LogY}$ & $\begin{array}{l}\text { LogTourism- } \\
\text { revenue }\end{array}$ & $\begin{array}{l}\text { LogTourism- } \\
\text { arrival }\end{array}$ \\
\hline Levin-Lin-Chu (LLC) & -3.388 *** & $-3.628 * * *$ & -0.633 \\
\hline Breitung & -3.480 & $-3.144 * * *$ & 3.186 \\
\hline Im-Pesaran-Shin (IPS) & $-2.390 * * *$ & $-2.442 * * *$ & -0.692 \\
\hline \multicolumn{4}{|c|}{ In the first difference } \\
\hline Method & $\Delta \log Y$ & $\begin{array}{l}\Delta \text { LogTourism- } \\
\text { revenue }\end{array}$ & $\begin{array}{l}\Delta \text { LogTourism } \\
\text {-arrival }\end{array}$ \\
\hline Levin-Lin-Chu (LLC) & $-9.238 * * *$ & $-9.263 * * *$ & $-7.945^{* * *}$ \\
\hline Breitung & $-3.206 * * *$ & $-4.364 * * *$ & $-5.038 * * *$ \\
\hline Im-Pesaran-Shin (IPS) & $-9.907 * * *$ & $-9.554 * * *$ & $-9.469 * * *$ \\
\hline
\end{tabular}

Notes: $* * *$ denotes significant at $1 \%$
Table 3. The Johansen-Fisher panel cointegration test result (Source: Calculated from the research data)

\begin{tabular}{|c|c|c|c|c|}
\hline \multirow{2}{*}{$\begin{array}{l}\text { Hypothesized } \\
\text { No. of Cointegration } \\
\text { Equation(s) }\end{array}$} & \multicolumn{2}{|c|}{$\begin{array}{l}\text { Fisher-statistic } \\
\text { (from Trace test) }\end{array}$} & \multicolumn{2}{|c|}{$\begin{array}{c}\text { Fisher-statistic } \\
\text { (from Max-Eigen } \\
\text { test) }\end{array}$} \\
\hline & Statistic & P-value & Statistic & P-value \\
\hline \multicolumn{5}{|c|}{$\begin{array}{l}\text { The independent variable is the } \\
\text { natural logarithm of tourism revenue }\end{array}$} \\
\hline None & $95.15 * * *$ & 0.000 & $67.91 * * *$ & 0.000 \\
\hline At most 1 & $62.25 * * *$ & 0.000 & $62.25^{* * *}$ & 0.000 \\
\hline \multicolumn{5}{|c|}{$\begin{array}{c}\text { The independent variable is the } \\
\text { natural logarithm of tourism arrival }\end{array}$} \\
\hline None & $136.5^{* * *}$ & 0.000 & $88.13 * * *$ & 0.000 \\
\hline At most 1 & $92.53 * * *$ & 0.000 & $92.53 * * *$ & 0.000 \\
\hline
\end{tabular}

Notes: $* * *$ denotes rejection of the null hypothesis at $1 \%$

Based on the unit root tests, the variables are expected to cointegrate at I(1) in all countries. The Johansen-Fisher cointegration test is applied to identify the existence of a long-run relationship between the variables in the countries (Maddala and $\mathrm{Wu}, 1999)$. The cointegration test helps to conclude that the variables might be cointegrated at I(1), otherwise, the regressive result maybe is a spurious estimate. The Johansen-Fisher cointegration test is done between the natural logarithm of the real GDP (LogY) and the natural logarithm of the real tourism revenue (LogTourism_revenue), on the other hand, between the natural logarithm of the real GDP (LogY) and the natural logarithm of the tourism arrival (LogTourism_arrival). The optimal lag length for the cointegration test is based on the suggestion of the Akaike information criterion (AIC). By using two indicators, the Trace statistic and Maximum eigenvalue statistic, the Johansen-Fisher tests confirm that there are 2 cointegration equations between tourism and economic growth in the study sample of transition economies. In detail, the null hypothesis of no cointegration $\left(\mathrm{H}_{0}\right)$ is rejected when these statistics are statistically significant at $1 \%$. The cointegration test results also imply the impact of tourism can be considered as an influencing variable in ensuring a cointegration relationship between tourism and economic growth in these countries. The results of the cointegration tests are reported in the below table.

The Johansen-Fisher cointegration tests conclude that there is the existence of long-run relationships running from tourism to economic growth in these transition countries (Maddala and Wu, 1999). Therefore, two long-run models can be estimated and then identify the sign and the significant level of received coefficients, which help to confirm the tourism-led growth hypothesis in the case of these countries. If the coefficients of LogTourism_revenue and LogTourism_arrival are positive and statistically significant, the tourism-led growth hypothesis will be confirmed, hence, these countries have come to be known as tourism-led growth economies. On the opposite side, this hypothesis can be rejected in the development process of these countries for the study period. However, as shown in Table 4, the tourism-led growth hypothesis can be concluded in these countries. The combined results from two long-run equations are in the below table.

Table 4. The panel estimated results (Source: Calculated from the research data)

\begin{tabular}{|c|c|c|c|c|c|c|}
\hline \multicolumn{7}{|c|}{ Dependent variable: The natural logarithm of real GDP $(\log Y)$} \\
\hline Variable & \multicolumn{2}{|c|}{ Pooled_OLS } & \multicolumn{2}{|c|}{ Fixed_effects } & \multicolumn{2}{|c|}{ Random_effects } \\
\hline Constant & $4.220 * * *$ & {$[8.617]$} & $4.686 * * *$ & {$[10.02]$} & $4.681 * * *$ & {$[9.659]$} \\
\hline LogTourism_revenue & $0.982 * * *$ & [49.15] & $0.963 * * *$ & [50.43] & $0.964 * * *$ & [51.11] \\
\hline R-squared & \multicolumn{2}{|c|}{0.9393} & \multicolumn{2}{|c|}{0.9679} & \multicolumn{2}{|c|}{0.9440} \\
\hline Adj-R squared & \multicolumn{2}{|c|}{0.9389} & \multicolumn{2}{|c|}{0.9665} & \multicolumn{2}{|c|}{0.9436} \\
\hline Observations & \multicolumn{2}{|c|}{158} & \multicolumn{2}{|c|}{158} & \multicolumn{2}{|c|}{158} \\
\hline \multicolumn{7}{|c|}{ Dependent variable: The natural logarithm of real GDP $(\log Y)$} \\
\hline Variable & \multicolumn{2}{|c|}{ Pooled_OLS } & \multicolumn{2}{|c|}{ Fixed_effects } & \multicolumn{2}{|c|}{ Random_effects } \\
\hline Constant & $10.26 * * *$ & [5.124] & -6.977 & {$[-1.550]$} & -0.356 & {$[-0.096]$} \\
\hline LogTourism_arrival & $1.075 * * *$ & [8.910] & $2.116^{* * *}$ & [7.791] & $1.716^{* * *}$ & [7.726] \\
\hline R-squared & \multicolumn{2}{|c|}{0.3145} & \multicolumn{2}{|c|}{0.5366} & \multicolumn{2}{|c|}{0.2505} \\
\hline Adj - R squared & \multicolumn{2}{|c|}{0.3105} & \multicolumn{2}{|c|}{0.5172} & \multicolumn{2}{|c|}{0.2462} \\
\hline Observations & \multicolumn{2}{|c|}{175} & \multicolumn{2}{|c|}{175} & \multicolumn{2}{|c|}{175} \\
\hline
\end{tabular}

Notes: $* * *$ denotes significant at $1 \%$, and t-statistic in the parentheses 
In Table 4, the estimated results of the long-run models obviously indicate that the tourism variables have positive and significant impacts on the economic growth at the significance of $1 \%$. The estimated results also are consistent between three methods including the pooled_OLS, the fixed effects and the random-effects. Therefore, the tourism-led growth hypothesis is confirmed in the case of seven transition countries. In detail, the elasticity of the tourism_revenue variable is around $1 \%$ with three methods, which implies that a $1 \%$ increase in the tourism revenue can lead to a $1 \%$ increase in economic growth in the long run. Besides, the estimated results also indicate that a $1 \%$ increase in the number of tourism arrivals makes a $1.075 \%$ (the pooled_OLS), a $2.116 \%$ (the fixed effects), a $1.716 \%$ (the random effects) increase in the annual growth rate of these economies, respectively. Furthermore, the quantitative results are suitable with the trend of the database shown in the above figures as well as the Johansen-Fisher congregation test in the previous section. The empirical results suggest that the tourism-led growth strategy is really a good development plan in long run in transition economies, which are changing from a centrally planned economy to a market economy.

Our empirical finding also helps to expand the previous results of in transition countries in the European region such as Payne and Mervar (2010) in Croatia, Surugiu and Surugiu (2013) in Romania, Gričar et al. (2021) in Montenegro and Slovenia, and in the Asian region such as Trang et al. (2014). Besides, our empirical result is the opposite of the previous result from Laos (a transition economy in Asia), because this economy had not confirmed the tourism-led growth hypothesis for the period of 1992-2014 (Kyophilavong et al., 2018). Some transition economics have met many huge achievements in economic development in recent decades as well as have successfully joined into the group of developed countries. However, our study highlights the tourism sector and tourism activities are still very helpful to establish an advantageous market economy with high competitiveness and high freedom in the business environment. Finally, our findings have not only expanded the empirical results but also filled the current research gap of tourism-growth nexus in the case of the group of the transition economies. The robust growth model of these transition economies needs to continue to be maintained and expanded the economic contributions from the tourism development variable.

\section{CONCLUSION}

The paper examines the tourism-led growth hypothesis in a group of transition countries, includes Bulgaria, Hungary, Poland, Romania, Russia, Ukraine and Vietnam, in the period of 1995-2019. These countries have had robust economic growth rates in recent decades. The Johansen-Fisher test confirms the existence of long-run cointegration relationships between tourism and economic growth in this group of countries. Besides, the panel estimated results show positive and significant impacts of tourism variables on economic growth at $1 \%$, which concludes the tourism-led growth hypothesis in the case of the transition economies. Based on the estimated results, our finding highlights that the policymakers should persist in applying the tourism-led growth strategies in the future.

From the perspective of policy implications, based on our evidence, tourism-led growth is concluded as a good national development strategy that helps to support economic growth in countries. Besides, the growth of tourism also helps the host economies to close links with the global value chains. In the future, the support for tourism sectors needs to consider in order to help this economic sector develop more sustainable in the future. On the other hand, the leaders in countries maybe note that the instability of the world economy and international health crisis (eg., a global pandemic) can push the tourismled growth economies into external crisis shocks. Although our empirical result implies that the expansion of tourism activities is an important factor of the economic development path in these countries, the potential risks from outsides can decrease when the domestic tourism of countries is stimulated and helps diverse demand from both inside and outside, therefore, the benefits in increasing tourism are stable in the long run. Besides, in order to sustainably develop the tourism sector, there are some possible solutions as follows, establish the dynamic link between the tourism sectors and the rest of the economies, invest more to increase the quality of infrastructure systems, and raise human resources in tourism sectors (eg., skilled labours). Finally, the transition economies need to continuously increase the competitiveness of their tourism sectors and join deeper in the global value chain of tourism services. Therefore, tourism-led growth can help them successfully enhance economic growth in this group of countries in the future.

\section{ACKNOWLEDGEMENT}

The author would like to thank the World Development Indicators (World Bank) for its free-access database. Besides, the constructive comments from the editor and referees are very helpful for increasing the quality of my paper.

\section{REFERENCES}

Aratuo, D.N., \& Etienne, X.L. (2019). Industry level analysis of tmyism-economic growth in the United States. Tourism Management, 70, 333-340. https://doi.org/10.1016/j.tourman.2018.09.004

Balaguer, J., \& Cantavella-Jordá, M. (2002). Tourism as a long-run economic growth factor: the Spanish case. Applied Economics, 34(7), 877-884. https://doi.org/10.1080/00036840110058923

Barro, R.J. (1991). Economic Growth in a Cross-section of Countries. Quarterly Journal of Economics, 106(2), 407-443. https://doi.org/10.2307/2937943

Brida, J.G., Cortes-Jimenez, I., \& Pulina, M. (2016). Has the tourism-led growth hypothesis been validated? A literature review. Current Issues in Tourism, 19(5), 394-430. https://doi.org/10.1080/13683500.2013.868414

Brida, J.G., \& Risso, W.A. (2010). Tourism as a determinant of long-run economic growth. Journal of Policy Research in Tourism, Leisure and Events, 2(1), 14-28. https://doi.org/10.1080/19407960903542276

Breitung, J. (2000). The Local Power of Some Unit Root Tests for Panel Data. In: B. Baltagi (Ed). Advances in Econometrics: Nonstationary Panels, Panel Cointegration, and Dynamic Panels, JAI Press, Amsterdam, 15, 161-178. 
Cárdenas-García, P.J., \& Sánchez-Rivero, M. (2015). Tourism and Economic Development: Analysis of Geographic Features and Infrastructure Provision. Current Issues in Tourism, 18(7), 609-32. https://doi.org/10.1080/13683500. 2013.860954

Chen, M.H. (2007). Interactions between business conditions and financial performance of tourism firms: Evidence from China and Taiwan. Tourism Management, 28(1), 188-203. https://doi.org/10.1016/j.tourman.2005.11.012

Firdaus, F., Shalihin, S., Anggreta, D.K., Yasin, F., \& Tutri, R. (2019). Improving the benefits of Karamba into tourism acti vities: An effort to reduce the ecological impact of aquaculture in Maninjau lake, Indonesia. GeoJournal of Tourism and Geosites, 26(3), 726736. https://doi.org/10.30892/gtg.26304-392

Garza-Rodriguez, J. (2019). Tourism and Poverty Reduction in Mexico: An ARDL Cointegration Approach. Sustainability, 11, 845. https://doi.org/10.3390/su11030845

Gričar, S., Bojnec, Š., Karadžić, V., \& Vulić, T.B. (2021). Tourism-led economic growth in Montenegro and Slovenia. Economic Research-Ekonomska Istraživanja (Forthcoming). https://doi.org/10.1080/1331677X.2021.1875858

Grossman, G.M., \& Helpman, E. (1990). Comparative advantage and long-run growth. American Economic Review, 80, $796-815$. https://www.jstor.org/stable/2006708

Im, K.S., Perasan, M.H., \& Shin, Y. (2003). Testing Unit Roots in Heterogeneous Panels. Journal of Econometrics, 115(1), 53-74. https://doi.org/10.1016/S0304-4076(03)00092-7

Ivanov, S., \& Webster, C. (2013). Tourism's impact on growth: the role of globalization. Annals of Tourism Research, 41, $231-236$. https://doi.org/10.1016/j.annals.2012.12.008

Katircioglu, S. (2009). Tourism, trade and growth: the case of Cyprus. Applied Economics, 41(21), 2741-275. https://doi.org/10. $1080 / 00036840701335512$

Katircioğlu, S. (2010). Testing the Tourism-Led Growth Hypothesis for Singapore - An Empirical Investigation from Bounds Test to Cointegration and Granger Causality Tests. Tourism Economics, 16(4), 1095-1101. https://doi.org/10.5367/te.2010.0012

Kyophilavong, P., Gallup, J.L., Charoenrat, T., \& Nozaki, K. (2018). Testing tourism-led growth hypothesis in Laos?. Tourism Review, 73(2), 242-251. https://doi.org/10.1108/TR-03-2017-0034

Levin, A., Lin C.F., \& Chu, C. (2002). Unit Root Tests in Panel Data: Asymptotic and Finite-Sample Properties. The Review of Financial Studies, 108(1), 1-24. https://doi.org/10.1016/S0304-4076(01)00098- 7

Lew, A.A. (2011). Tourism's Role in the Global Economy. Tourism Geographies, 13(1), 148-151. https://doi.org/ 10.1080/14616688.2010.531046

Lim, C., \& Zhu, L. (2017). Dynamic heterogeneous panel data analysis of tourism demand for Singapore. Journal of Travel \& Tourism Marketing, 34(9), 1224-1234. https://doi.org/10.1080/10548408.2017.1330173

Maddala, G.S., \& Wu, S. (1999). A comparative study of unit root tests with panel data and a new simple test. Oxford Bulletin of Economics and Statistics, 61(S1), 631-652. https://doi.org/10.1111/1468-0084.0610s1631

Njoya, E.T., \& Seetaram, N. (2017). Tourism Contribution to Poverty Alleviation in Kenya: A Dynamic Computable General Equilibrium Analysis. Journal of Travel Research, 57(4), 513-524. https://doi.org/10.1177/0047287517700317

Nowak, J.J., Sahli, M., \& Cortés-Jiménez, I. (2007). Tourism, Capital good imports and economic growth: theory and evidence for Spain. Tourism Economics, 13(4), 515-553. https://doi.org/10.5367/000000007782696113

Pablo-Romero, M.P., \& Molina, J.A. (2013). Tourism and economic growth: A review of empirical literature. Tourism Management Perspectives, 8, 28-41. https://doi.org/10.1016/j.tmp.2013.05.006

Payne, J.E., \& Mervar, A. (2010). The Tourism's Growth Nexus in Croatia. Tourism Economics, 16(4), 1089-1094. https:// doi.org/10.5367/te.2010.0014

Scott, D., Gössling, S., Hall, C.M., \& Peeters, P. (2016). Can tourism be part of the decarbonized global economy? The costs and risks of alternate carbon reduction policy pathways. Journal of Sustainable Tourism, 24(1), 52-72. https://doi.org/10.1080/09669582.2015.1107080

Seetanah, B. (2011). Assessing the dynamic economic impact of tourism for island economies. Annals of Tourism Research, 38(1), $291-308$.

Shahzad, S.J.H., Shahbaz, M., Ferrer, R., \& Kumar, R.R. (2017). Tourism-led growth hypothesis in the top ten tourist destinations: New evidence using the quantile-on-quantile approach. Tourism Management, 60, 223-232.

Saayman, M., Rossouw, R., \& Krugell, W. (2012). The impact of tourism on poverty in South Africa. Development Southern Africa, $29(3), 462-487$.

Strydom, A.J., Mangope, D., \& Henama, U.S. (2019). Making community-Based tourism sustainable: Evidence from the free state province, South Africa. GeoJournal of Tourism and Geosites, 24(1), 7-18. https://doi.org/10.30892/gtg.24101-338

Surugiu, C., \& Surugiu, M.R. (2013). Is the tourism sector supportive of economic growth? Empirical evidence on Romanian tourism. Tourism Economics, 19(1), 115-132. https://doi.org/10.1080/09669582.2015.1107080

Trang, N.H.M., Duc, N.H.C., \& Dung, N.T. (2014). Empirical assessment of the tourism-led growth hypothesis - the case of Vietnam. Tourism Economics, 20(4), 885-892. https://doi.org/10.5367/te.2013.0307

Tugcu, C.T. (2014). Tourism and economic growth nexus revisited: A panel causality analysis for the case of the Mediterranean Region. Tourism Management, 42, 207-212. https://doi.org/10.1016/j.tourman.2013.12.007

Tung, L.T. (2020). Tourism development in Vietnam: New strategy for a sustainable pathway. Geojournal of Tourism and Geosites, 31(3), 1174-1179. https://doi.org/10.30892/gtg.31332-555

Tung, L.T., \& Cuong, L.K. (2020). Impact of Tourism on Poverty Reduction: Evidence from an Emerging Tourism Market. Montenegrin Journal of Economics, 16(3), 45-55. https://doi.org/10.14254/1800-5845/2020.16-3.4

Weidenfeld, A. (2013). Tourism and Cross Border Regional Innovation Systems. Annals of Tourism Research, 42, $191-213$. https://doi.org/10.1016/j.annals.2013.01.003

***World Bank. (2021a). GDP per capita, PPP (current international \$). World Development Indicators online database. Washington, DC. Retrieved from https://data.worldbank.org/indicator/NY.GDP.PCAP.PP.CD?view=chart

***World Bank. (2021b). International tourism, number of arrivals. World Development Indicators online database. Washington, DC. Retrieved from https://data.worldbank.org/indicator/ST.INT.ARVL?view=chart

***World Bank. (2021c). International tourism, expenditures (current USD). World Development Indicators online database. Washington, DC. Retrieved from https://data.worldbank.org/indicator/ST.INT.XPND.CD?view=chart

***World Economic Forum (WEF) (2019). The Travel \& Tourism Competitiveness Report 2019. Retrieved from https://www. weforum.org/reports/the-travel-tourism-competitiveness-report-2019 